\title{
OCENĚNÍ POMOCÍ RTS BIM
}

\author{
VALUATION USING RTS BIM
}

\author{
Aleš Průcha ${ }^{*}, 1$ \\ *Ales.Prucha@vut.cz \\ ${ }^{2}$ Vysoké učení technické v Brně, Fakulta stavební, Veveří 331/95, 60200 Brno
}

\begin{abstract}
Abstrakt
Tento článek se zabývá oceňováním s využitím BIM. Cílem tohoto článku je ocenit stavbu pomocí BIM modelu nákladovým způsobem. Článek se zabývá popisem BIM problematiky, dále zaváděním a potřebou BIM ve stavebnictví. Obsahuje popis metod ocenění včetně ocenění vybrané konstrukce jednotlivými metodami. Jednotlivé metody jsou poté porovnány s nákladovým způsobem ocenění pomocí RTS BIM.
\end{abstract}

\section{Klíčová slova}

BIM, informační model budovy, nákladový způsob ocenění

\section{Abstract}

This article deals with valuation using BIM. The aim of this article is to appraise the construction using the BIM model in cost approach. The article deals with the description of BIM implementation and the need for BIM in construction. It contains a description of valuation methods, including the valuation of selected structures by individual methods. The individual methods are compared with the cost approach using RTS BIM.

\section{Key words}

BIM, building information model, cost approach

\section{1 ÚVOD}

Cílem tohoto článku je obsažení základních faktů a poznatků o BIM. Článek popisuje základní metodiku nákladového ocenění. Nosnou částí článku je postup ocenění pomocí RTS BIM, kde jsou detailně popsány jednotlivé kroky vedoucí k úplnému ocenění vybrané konstrukce. Ve výsledkové části jsou vloženy jednotlivé výsledky získané pomocí tvorby položkového rozpočtu a RTS BIM. V závěru jsou tyto dvě metody porovnány a dále metoda srovnána v kontextu ostatních řešení.

\section{IMPLEMENTACE BIM V ČESKÉ REPUBLICE}

V České republice se o problematiku BIM začala zajímat vláda až v roce 2016, kdy vydala rozhodnutí vlády o významu metod BIM a pověrila Ministerstvo průmyslu a obchodu, aby vypracovalo plán pro implementaci ve stavebnictví. V návaznosti na vypracovaný plán byl přijat nový zákon, který pojednává o zadávání veřejných zakázek a možnosti vyžadování BIM [1].

V roce 2017 byla schválena koncepce zavádění BIM v České republice, kde je obsažen návrh na postupnou implementaci BIM, kdy zlomovým okamžikem měl být rok 2022, který je spojen se zavedením povinnosti použití BIM u nadlimitních veřejných zakázek na stavební práce od 1. 1. 2022, avšak vláda tento termín posunula na 7/2023 s postupnou účinností [1].

\section{NÁKLADOVÉ OCENĚNÍ POMOCÍ RTS BIM}

Ocenění pomocí BIM má velký potenciál v praktickém využití u nákladového způsobu ocenění. V praxi to znamená vytvoření editovatelného položkového rozpočtu s výkazem výměr na základě vstupů dodávaných přímo z modelu v podobě výkazu výměr. Každý prvek či konstrukce 3D modelu může mít libovolný počet rozměrových 
vlastností (výška, šiřka, plocha, délka, objem) a další technické specifikace, které jsou již do modelu na základě zatřídění.

Samotná práce rozpočtáře na ocenění probíhá př́mo v nativním prostředí aplikace REVIT pomocí pluginu a je tedy zajištěna kontinuita všech částí projekce.

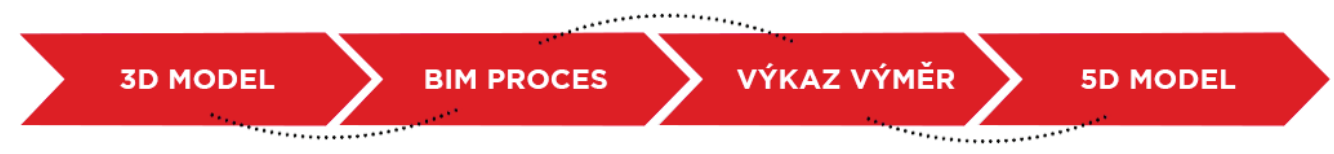

Obr. 1 Postup dat v BIM modelu [2].

\title{
Klasifikační systém RTS BIM
}

Pro použití ocenění BIM společnost vyvinula vlastní klasifikační systém, který byl vytvořen právě pro BIM modelování. Klasifikačním systémem je Jednotná klasifikace stavebních objektů. Základní členění je dále rozšířeno o konstrukční prvky a jejich technické specifikace.

Na základní obor objektu je tedy dále navázána čtyřstupňová struktura - Funkční díl $\rightarrow$ Podfunkční díl $\rightarrow$ konstrukční prvek $\rightarrow$ technická specifikace [3].

\author{
Klasifikační systém podle RTS \\ 1. Zemni práce \\ 2. Zảkladové konstrukce \\ 3. Svislè konstrukce \\ 4. Vodorovné konstrukce \\ 5. Strešni konstrukce \\ 6. Povrchy vnitřnich a vnëjšich konstrukci \\ 7. Výplnè otvorủ \\ 8. Podlahové konstrukce \\ 9. Instalace \\ 10. Ostatni \\ 11. Vnējši úpravy a úpravy územi
}

Obr. 2 Klasifikační systém RTS BIM [4].

\section{Datový standard RTS}

Datový standard se skládá ze čtyř skupin parametrů. Jednotlivé parametry jsou seřazeny do 4 skupin. První skupinou jsou geometrické informace, které získáváme přímo z BIM modelu - jedná se o délku, šířku, výšku, objem, atd. Druhou skupinou jsou informační parametry jako jsou označení místnosti či podlaží. Třetí skupinou jsou technické parametry, které si uživatel zadává dle požadavků na konstrukce jako je stupeň vyztužení či specifikace betonu. Poslední čtvrtým parametrem je parametr procesní, který by měl eliminovat nepřesnosti ve výpočtu způsobené absencí některých konstrukcích v modelu např́iklad vlivem nižšího stupně tzv. Level of Detail tedy úrovně detailu daného modelu [3].

\section{POSTUP OCENĚNÍ}

\section{Vytvoření zakázky v RTS CLOUD BIM MANAGERU}

Pro oceňování je vytvořeno webové rozhraní Cloud BIM Manager, kde je nutné vytvořit zakázku. Zde následně probíhá samotný výpočet ceny za stavbu [5]. 


\section{Zatřídění konstrukce a přiřazení parametrů}

Pro ocenění pracujete hlavně v pluginu, který je nainstalován př́mo do aplikace REVIT a tudíž se všechny změny okamžitě propisují prímo do modelu i rozpočtu.

Prvním krokem ocenění je zatřídění konstrukce v klasifikačním systému RTS BIM. Pro tento článek byla zvolena konstrukce základové desky monolitické železobetonové [5].

Zatřídění monolitické železobetonové základové desky:

02 - Základové konstrukce

Funkční díl

0201 - Základové konstrukce plošné

Podfunkční díl

020102 - Základové desky

020102-12 - Základové desky monolitické

Konstrukční prvek

020102-1251 - Základové desky monolitické železobetonové

Technická specifikace

Technická specifikace

Následujícím krokem je přesun do pluginu RTS Manager, kde se nastavují 4 skupiny parametrů. U technických parametrů se nastavuje např́klad třída pevnosti betonu nebo stupeň vyztužení. Dále můžeme nastavit hydroizolační vrstvy nebo bednění konstrukce. U geometrických informací přebíráme informace přímo z aplikace REVIT, které aplikace sama vypočte. Informační parametr je možné nastavit z důvodu př́padných soupisů jednotlivých prvků dle určeného klíče. Procesní parametr je v prŕípadě základové desky využit k přidání podsypu pod základovou deskou [5].

\section{Ocenění pomocí aplikace BIM na RTS CLOUD}

Po nastavení a odeslání informací z aplikace REVIT dochází k vlastnímu ocenění v prostředí webového rozhraní, kde je možné dále rozpočet upravovat podle požadavků rozpočtáře, popř́ípadě přidat konstrukce, které v modelu nebyly obsaženy. Poté je možno načíst rozpočet zpět do aplikace.

Výstupem z BIM CLOUDU je soupis technických specifikací včetně ceny [5].

\section{VÝSLEDKY}

19522 Základové desky monolitické železobetonové

\begin{tabular}{|c|c|c|c|}
\hline & Cena za MJ & Hodnota & Cena celkem \\
\hline Materiály & & & $272055,83 \mathrm{KČ}$ \\
\hline Beton & $2438,71 \mathrm{Kč}$ & 49,32840 & 120297,66 Kč \\
\hline Hydroizolační vrstva - asfalt. pásy - 1. vrstva & 145,14 Kč & 216,25200 & 31386,82 KČ \\
\hline Hydroizolační vrstva - asfalt. pásy - 2. vrstva & $145,14 \mathrm{Kč}$ & 216,25200 & $31386,82 \mathrm{Kč}$ \\
\hline Hydroizolační vrstva - asfalt. pásy - penetrace & $58,39 \mathrm{Kč}$ & 41,44830 & $2420,17 \mathrm{KC̆}$ \\
\hline Výztuž & 14770,06 Kč & 5,86080 & $86564,37 \mathrm{KC̆}$ \\
\hline Technologie & & & 100 092,95 Kс̌ \\
\hline Bednění - odstranění & $127,00 \mathrm{Kč}$ & 17,40000 & $2209,80 \mathrm{KC}$ \\
\hline Bednění - zřízení & $791,00 \mathrm{Kč}$ & 17,40000 & $13763,40 \mathrm{KC}$ \\
\hline Beton & $284,00 \mathrm{Kč}$ & 48,84000 & $13870,56 \mathrm{Kc}$ \\
\hline Hydroizolační vrstva - asfalt.pás - penetrace & $12,40 \mathrm{Kč}$ & 180,21000 & $2234,60 \mathrm{Kc̆}$ \\
\hline Výztuž & $11605,00 \mathrm{Kč}$ & 5,86080 & $68014,58 \mathrm{KČ}$ \\
\hline
\end{tabular}

Obr. 3 Rozpad ceny železobetonové základové desky [5]. 


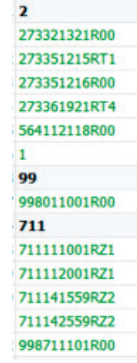

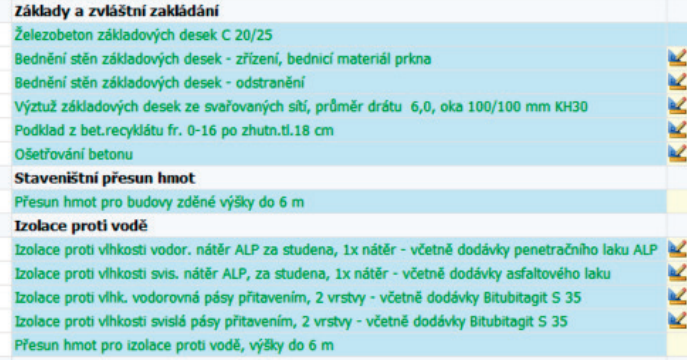

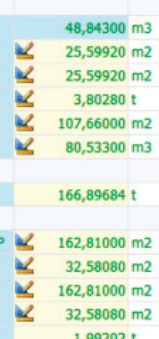

\begin{tabular}{|c|c|c|}
\hline & & 292220,10 \\
\hline 2860,00 & RTS $21 / 1$ & 139690,98 \\
\hline 536,00 & RTS $21 / 1$ & 13721,17 \\
\hline 127,00 & RTS $21 / \mathrm{I}$ & 3251,10 \\
\hline 31050,00 & RTS 21/ I & 118076,94 \\
\hline 110,00 & RTS 21/ I & 11842,60 \\
\hline \multirow{2}{*}{\multicolumn{2}{|c|}{70,00 Kalkul }} & 5637,31 \\
\hline & & 57746,31 \\
\hline \multirow{2}{*}{\multicolumn{2}{|c|}{346,00 RTS $21 /$ I }} & 57746,31 \\
\hline & & 86886,52 \\
\hline 30,90 & RTS 21/ I & 5030,83 \\
\hline 45,20 & RTS 21/ I & 1472,65 \\
\hline 394,50 & RTS 21/ I & 64228,55 \\
\hline 437,50 & RTS 21/ I & 14254,10 \\
\hline 954,00 & RTS 21/ I & 1900,39 \\
\hline
\end{tabular}

Obr. 4 Položkový rozpočet BuildPower S.

Tab. 1 Porovnání cen použitých metod ocenění.

\begin{tabular}{cccc}
\hline Použitá metoda & Cena bez DPH & \% rozdil & Cenový rozdíl \\
\hline Položkový rozpočet & $436852,93 \mathrm{Kč}$ & $0,00 \%$ & $0,00 \mathrm{Kč}$ \\
BIM RTS & $372148,78 \mathrm{Kč}$ & $-17,39 \%$ & $-64704,15 \mathrm{Kč}$ \\
\hline
\end{tabular}

\section{DISKUZE}

Ze získaných výsledků je patrné, že cena získaná pomocí metody BIM je velice přesná a rozdíl činí oproti položkovému rozpočtu $-17,39$ \%. Musíme však vzít v úvahu, že RTS BIM byl v době zpracování článku ve vývojářské verzi a proto neobsahoval přesuny hmot, které by již v ostré public verzi měly být. V položkovém rozpočtu přesuny hmot tvořili cenu 59 646,70 Kč. Po odečtení této hodnoty již dostáváme na rozdíl 1,16 \% a výsledek tedy můžeme považovat za velice přesný.

\section{ZÁVĚR}

Rozpočtování pomocí BIM je v České republice stále v začátcích a každá společnost přistupuje $\mathrm{k}$ řešení této problematiky jiným způsobem. Měl jsem možnost vyzkoušet několik řešení od různých společností, avšak platforma RTS BIM je koncepčně pojata z mého pohledu nejlépe. Na rozdíl od ostatních řešení totiž RTS BIM pracuje přímo $\mathrm{v}$ aplikaci REVIT, a proto je schopna reagovat na veškeré změny, které v projektu nastávají okamžitě, což ostatní řešení neumožňují, protože fungují na principu exportu dat mimo aplikace na tvorbu modelů.

\section{Poděkování}

Článek vznikl v rámci řešení juniorského specifického výzkumu č FAST-J-21-7378 „Analýza stavebnětechnologických procesů při realizaci, provozování a údržbě environmentálně šetrného zastřešení budov“.

\section{Použité zdroje}

[1] Koncepce BIM. Česká agentura pro standardizaci [online]. [cit. 2021-11-28]. Dostupné z: https://www.agentura-cas.cz/odbor-koncepce-bim/bim-koncepce/

[2] BIM Rozpočtování. Callida.cz [online]. [cit. 2021-11-15]. Dostupné z: https://callida.cz/cs/bim

[3] VARMUS, Tomáš. Jak ocenit stavby projektované pomocí BIM. Zprávy a informace ČKAIT [online]. Brno, 2020, 2020 [cit. 2021-11-20]. Dostupné z: http://zpravy.ckait.cz/vydani/2020-02/jak-ocenitstavby-projektovane-pomoci-bim/

[4] Cenové ukazatele. Cenová soustava [online]. RTS, 2021 [cit. 2021-10-8]. Dostupné z: https:/www.cenovasoustava.cz/default.asp?Typ=1\&ID=3\&BId=3\&Pop=1\&IDmH=3344891\&Menu= Cenov\%E9\%20ukazatele

[5] Ing. Aleš Průcha Ocenění s využitím informačního modelu budovy. Brno, 2021. 100 s. Diplomová práce. Vysoké učení technické v Brně, Ústav soudního inženýrství. Vedoucí práce Ing. et. Ing. Daniel Kliment. 